\title{
An empirical study on identifying critical success factors on chaos management
}

\author{
Naser Azad $^{\mathbf{a}^{*}}$ and Effat Haghighi ${ }^{\mathbf{b}}$
}

\begin{tabular}{l}
${ }^{a}$ Department of Management, Islamic \\
${ }^{b}$ Department of Management, Payame \\
\hline A R T I C L E I N F O \\
\hline Article history: \\
Received October 15, 2011 \\
Received in Revised form \\
November, 14, 2011 \\
Accepted 25 February 2012 \\
Available online \\
11 March 2012 \\
\hline Keywords: \\
Critical success factors \\
LISREL \\
Chaos management \\
Factor analysis
\end{tabular}

\begin{abstract}
Chaos management is one of the most necessary efforts on managing business units. Many organizations fail to cope with undesirable circumstances, which may happen without any prior notice and as a result, they may face with significant financial losses. In this paper, we present an empirical study to determine critical success factors, which could help handle any possible chaos in organizations. The proposed study of this paper is implemented for a set of travel agencies located in Tehran, Iran. Chronbach alpha is calculated as 0.821 , which is well above the minimum desirable level. In addition, we have also performed factor analysis, which yields a KMO value of 0.576 with the level of significance of 0.000 . The results indicate that there are six important factors including effective management strategy, internal environmental factors, creative and innovative attitudes, external environmental factors and top level management thoughts.
\end{abstract}

(C) 2012 Growing Science Ltd. All rights reserved.

\section{Introduction}

One of the most important issues surrounding business units is to handle any chaos happens specially in tourism industry. Travel agencies as part of this industry may face with many challenges in different occasions such as revolution incidents, terrorist attacks, airport strike, etc. Organizational crises are relatively low-probability, high-impact situations, which threaten the competitiveness and viability of a firm (Valackiene, 2010). In such circumstances, it is important for managers of these agencies to handle the events as efficiently as possible. There are different studies associated with chaos management and there are several suggestions on reducing the cost of such incidents. Jallat and Shultz (2010) performed an empirical investigation for the country of Lebnon. This country has been located in a region where there are many threats including recent military assaults, terroris tattacks, etc. They shared their findings from a longitudinal field-study of political and business climate of Lebanon and presented their insight on how to handle different conflicts.

\footnotetext{
* Corresponding author. Tel. + 982122895719

E-mail addresses: dr.naserazad@yahoo.com (N. Azad) 
Pearson and Sommer (2011) explained the need to infuse creativity into organizational crisis management may be more necessary now than ever. Despite the fact that many investigations on creativity recommends that time pressure stifles innovation, we also need to know how to foster creativity when time pressure exists, when uncertainty increases and when crises loom.

Liu et al. (2009) performed an interview based investigation among 22 Chinese executives to find out their perception on four issues of crises: causes, consequences, caution and coping. They recommended that the informants could blame external constituencies for frequent adverse events experienced by Chinese business units and equate crisis management with quick problem solving in which technical protection of corporate image via effective leadership was the top priority. They also provided an alternative solution of thinking about crisis management, i.e., a manager's self positioning within the larger socio-economic context.

Israeli et al. (2011) investigated hospitality crisis management practices based on the context of the Indian hospitality industry. They used a questionnaire, which evaluated the relative importance and usage of four issues including marketing, hotel maintenance, human resources and governmental assistance. They reported which practices managers were important and which practices managers virtually implement during a crisis.

Tarraf (2011) investigated the role of corportae governance in the events leading up to the global financial crisis: Analysis of aggressive risk-taking. He looked for an explanation on how failures in corporate governance contributed to the global financial crisis. In other words, he tried to find out how the current corporate governance systems failed to safeguard against aggressive risk taking. He reported that aggressive risk taking was a major cause of the 2007-2008 financial crisis. Inadequate risk management by executives and boards of directors were among the most important reasons for the credit market collapse and resulting financial crisis. The results also contributed directly to understanding what went wrong in the corporate governance system based on a review of the literature. Eriksson and McConnell (2011) proposed that the relationship between crisis planning and crisis management outcomes could be more complex and nuanced relationship the often assumed.

Miller (2002) performed a research, which highlights passengers experience throughout the crisis. The survey shows that just $90 \%$ of respondents highlighted the failure of airline, travel agencies and/or government to provide suitable information. The airspace closure also created adverse health influence, with $79 \%$ of respondents highlighting this as a concern. Carmeli and Schaubroeck (2008) performed a study, which indicated that learning from failures is an necessary facilitator of preparedness for both present and prospective crises.

Although crisis experience and an industry's technological risk were not substantially associated with crisis preparedness, high-performing organizations are believed to have higher levels of crisispreparedness. Choi et al. (2010) performed an investigation, which was based on qualitative and quantitative analyses of 30 crisis real-world case studies. The study also identified the prevalent types of crises and efficient strategies used for team crisis coping. The results revealed that $90 \%$ of team level crises were caused by external or environmental factors rather than internal disturbances.

In this paper, we present an empirical study to determine critical success factors, which could help handle any possible chaos in organizations. The proposed study of this paper is implemented for a set of travel agencies located in Tehran, Iran.

\section{Proposed model}

The proposed study of this paper tries to indentify important factors, which could help handle crises. The study has designed a questionnaire and distributed among experts in travel agencies. Chronbach 
Alpha has been calculated as 0.821 , which is well above the minimum requirement. The study has chosen six factors as follows,

1. Knowledge, innovation, new business strategies: This includes performance measurement of managers during crises, continuous review on chaos management, economic recession of organization, presenting innovative ideas, etc.

2. Specific management programs: This includes long term planning for future crises, selective programs for better handling crises, etc.

3. Internal environmental factors: This includes financial turmoil, learning from experiences on different crises, etc.

4. Creative and innovative thoughts: This includes heuristic and innovative ideas to handle chaos.

5. External environmental factors: This includes issues on how to become cope with changes in the environment.

6. Top management perspectives: This includes how top management could handle challenges.

Let F1 to F6 denote effective management strategies, specific management programs, internal factors, creative and innovative thoughts, external factors and top management perspectives, respectively.

\section{Results}

We have used LISREL software package to analyze the results of this survey. Fig. 1 shows the effects of different factors on

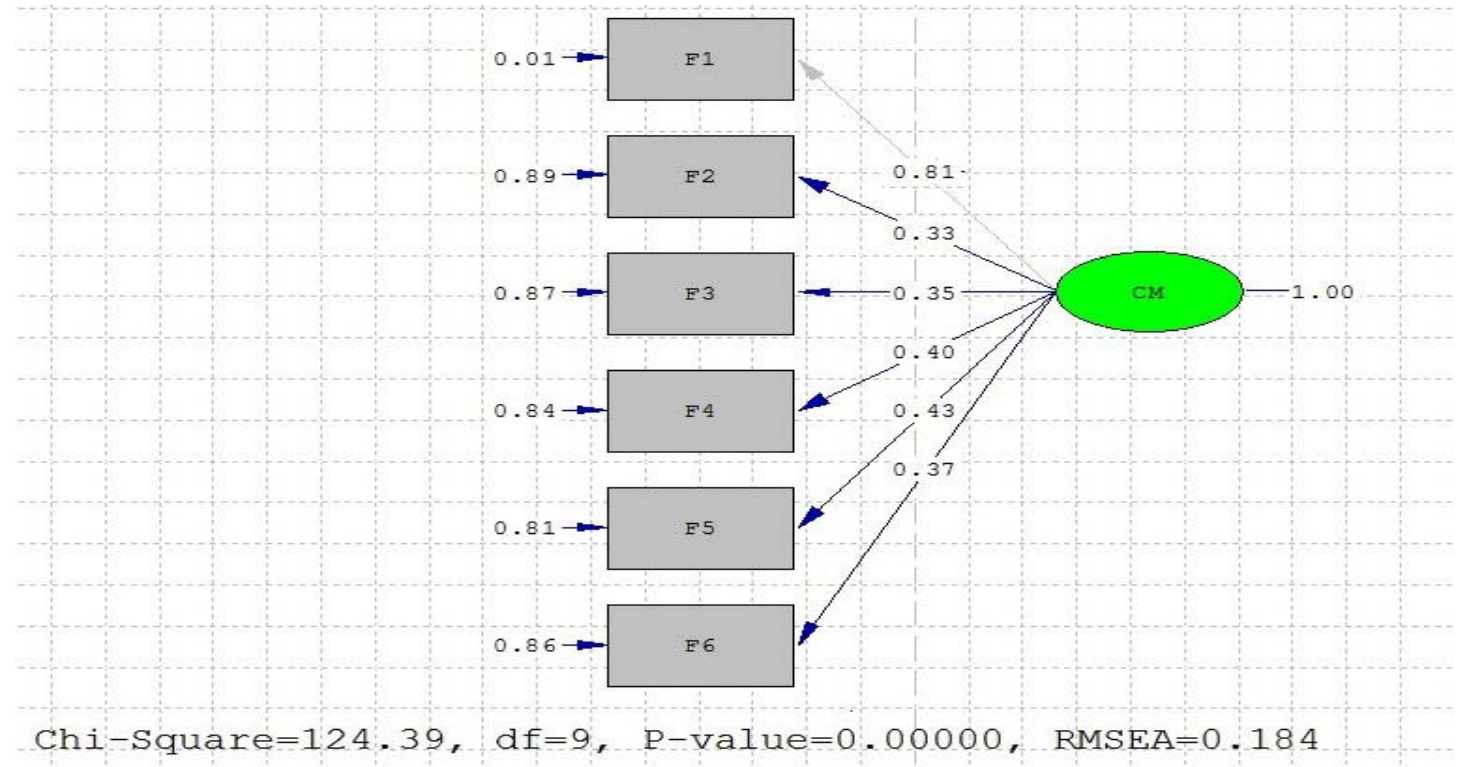

Fig. 1. The results of six factors on crises management (CM)

As we can observe from the results, $\chi^{2}=124.39$ with 9 degrees of freedom, which is well above the critical value of 3 and RMSEA is 0.184 , which is above the critical value of 0.08 . Table 1 shows details of other statistical observations. 


\section{Table 1}

Statistical observations of LISREL test in the first stage

\begin{tabular}{|c|c|c|c|c|c|c|c|}
\hline Factor & $\begin{array}{r}\text { Estimated } \\
\text { value }\end{array}$ & $\begin{array}{r}\text { Standard } \\
\text { value }\end{array}$ & $\begin{array}{r}\text { Standard } \\
\text { error }\end{array}$ & t-value & Variance & P-value & Result \\
\hline $\begin{array}{l}\text { effective management } \\
\text { strategies }\end{array}$ & 1.00 & 0.81 & & & 0.81 & $\mathrm{P}<0.01$ & Confirmed \\
\hline $\begin{array}{l}\text { specific management } \\
\text { programs }\end{array}$ & 0.08 & 0.33 & 0.014 & 3.19 & 0.11 & $\mathrm{P}<0.01$ & Confirmed \\
\hline internal factors & 0.08 & 0.35 & 0.014 & 3.36 & 0.13 & $\mathrm{P}<0.01$ & Confirmed \\
\hline $\begin{array}{l}\text { creative and innovative } \\
\text { thoughts }\end{array}$ & 0.09 & 0.4 & 0.014 & 3.65 & 0.16 & $\mathrm{P}<0.01$ & Confirmed \\
\hline external factors & 0.1 & 0.43 & 0.062 & 3.87 & 0.19 & $\mathrm{P}<0.01$ & Confirmed \\
\hline $\begin{array}{l}\text { top management } \\
\text { perspectives }\end{array}$ & 0.09 & 0.37 & 0.014 & 3.48 & 0.14 & $\mathrm{P}<0.01$ & Confirmed \\
\hline
\end{tabular}

Table 2 shows other statistical observations associated with the proposed study. The first row represents chi square divided to degree of freedom and based on the value of 12.93 we reject the model. The second row represents root mean square error of approximation and the third row goodness of fit index. The results of these two tests lead us to accept the model. Comperation fit index (CFI) and Inceremental fit index (IFI) also reject the model.

\section{Table 2}

Statistical observations

\begin{tabular}{lccc}
\hline Index & Acceptable region & Value & Result \\
\hline $\mathrm{X}^{2} / \mathrm{df}$ & $\leq 3 \mathrm{X} 2 / \mathrm{df}$ & 12.93 & Reject \\
RMSEA & RMSEA $<0.09$ & 0.000 & Accept \\
GFI & GFI $>0.9$ & 0.9 & Accept \\
AGFI & AGFI $>0.85$ & 0.77 & Reject \\
CFI & CFI $>0.90$ & 0.73 & Reject \\
IFI & IFI $>0.90$ & 0.53 & Reject \\
\hline
\end{tabular}

Fig. 2 shows details of our survey in the final stage.

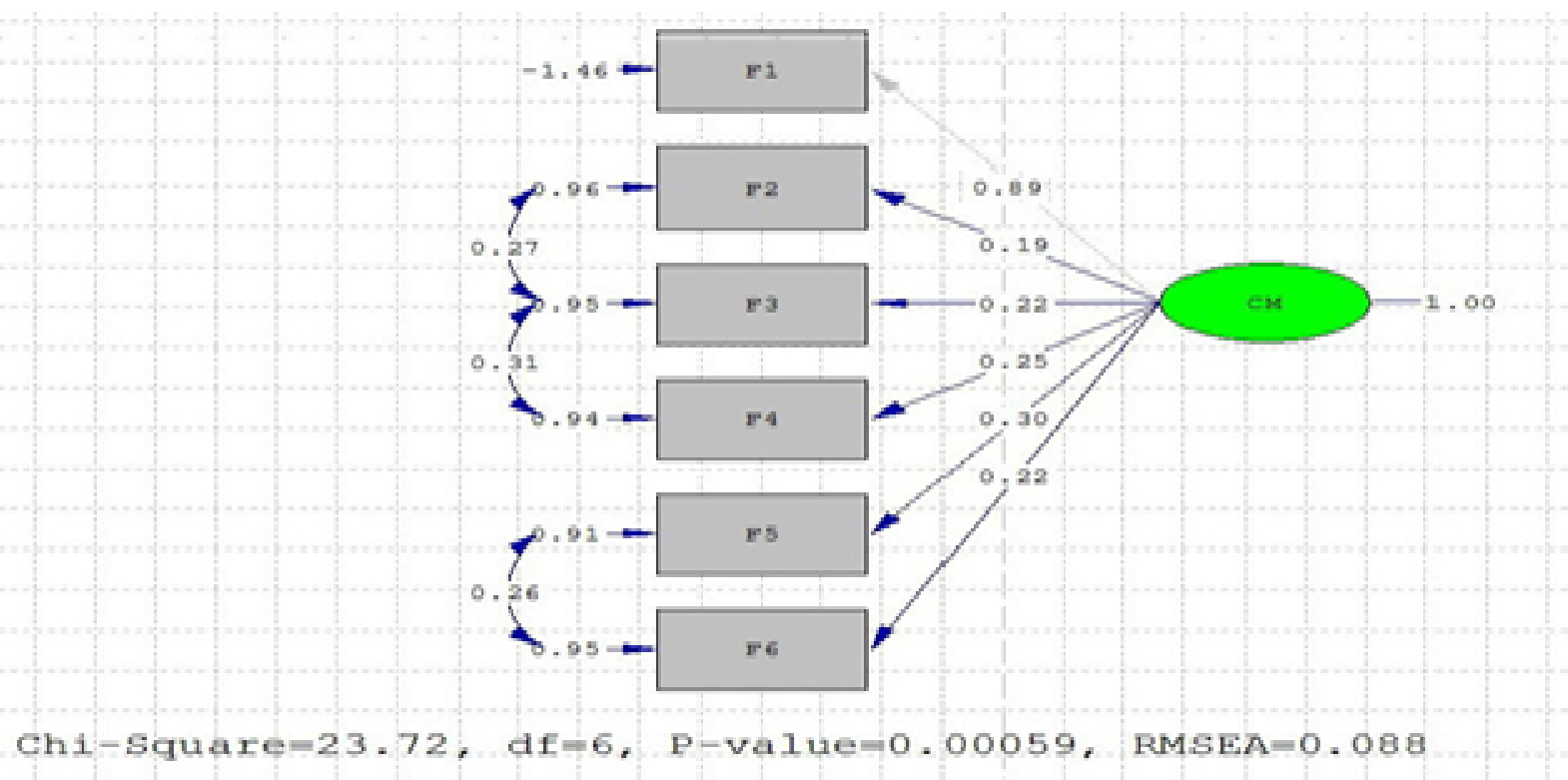

Fig. 2. The results of six factors on crises management (CM) 
Table 3 shows details of other statistical observations.

Table 3

Statistical observations of LISREL test in the final stage

\begin{tabular}{lrrrrrrr}
\hline Factor & $\begin{array}{r}\text { Estimated } \\
\text { value }\end{array}$ & $\begin{array}{r}\text { Standard } \\
\text { value }\end{array}$ & $\begin{array}{r}\text { Standard } \\
\text { error }\end{array}$ & $\begin{array}{r}\text { t- } \\
\text { value }\end{array}$ & Variance & $\begin{array}{r}\mathrm{P}- \\
\text { value }\end{array}$ & Result \\
\hline $\begin{array}{l}\text { effective management } \\
\text { strategies }\end{array}$ & 1.00 & 0.89 & 10 & & 0.89 & $\mathrm{P}<0.01$ & Confirmed \\
$\begin{array}{l}\text { specific management } \\
\text { programs }\end{array}$ & 0.03 & 0.19 & 0.013 & 2.25 & 0.12 & $\mathrm{P}<0.01$ & Confirmed \\
$\begin{array}{l}\text { internal factors } \\
\begin{array}{l}\text { creative and innovative } \\
\text { thoughts }\end{array}\end{array}$ & 0.03 & 0.22 & 0.014 & 2.34 & 0.13 & $\mathrm{P}<0.01$ & Confirmed \\
$\begin{array}{l}\text { external factors } \\
\text { top management }\end{array}$ & 0.04 & 0.25 & 0.016 & 2.36 & 0.17 & $\mathrm{P}<0.01$ & Confirmed \\
perspectives & 0.04 & 0.30 & 0.018 & 2.45 & 0.17 & $\mathrm{P}<0.01$ & Confirmed \\
\hline
\end{tabular}

Based on the results of Table 3, we can conclude that all six factors play important role on managing crises. Table 4 demonstrates all other statistical observations.

Table 4

Statistical observations

\begin{tabular}{lccc}
\hline Index & Acceptable region & Value & Result \\
\hline $\mathrm{X}^{2} / \mathrm{df}$ & $\leq 3 \times 2 /$ df & 2.77 & Accept \\
RMSEA & RMSEA $<0.09$ & 0.390 & Accept \\
GFI & GFI $>0.9$ & 0.98 & Accept \\
AGFI & AGFI $>0.85$ & 0.96 & Accept \\
CFI & CFI $>0.90$ & 0.96 & Accept \\
IFI & IFI $>0.90$ & 0.90 & Accept \\
NNFI & NNFI $>0.90$ & 0.90 & Accept \\
\hline
\end{tabular}

Again, we can observe that all statistical values are meaningful and we can conclude that all six factors significantly influence the main factor, Crises Management (CM).

\section{Conclusion}

In this paper, we have performed an empirical investigation to detect important factors influencing crises management. The proposed study has distributed some questionnaire among different decision makers and analyzed the results using LISREL software package. The results has confirmed that all main six factors of effective management strategy, internal environmental factors, creative and innovative attitudes, external environmental factors and top level management thoughts could significantly impact managing crises.

\section{Acknowledgment}

The authors would like to thank the people who patiently participated in our survey and discussed all concerns. 


\section{References}

Cronbach, L. J. (1951). Coefficient alpha and the internal structure of tests. Psychometrika, 16(3), 297-334.

Carmeli, A., \& Schaubroeck, J. (2008). Organisational Crisis-Preparedness: The Importance of Learning from Failures. Long Range Planning, 177-196.

Choi, J.N., Sung, S.Y., \& Kim, M.U. (2010). How do groups react to unexpected threats? Crisis management in organizational teams. Social Behavior and Personality, 38(6), 805-828.

Eriksson, K., \& McConnell, A. (2011). Contingency planning for crisis management: Recipe for success or political fantasy? Policy and Society, 30(2), 89-99.

Likert, R. (1932). A Technique for the Measurement of Attitudes. Archives of Psychology, 140, 1-55.

Israeli, A.A., Mohsin, A., \& Kumar, B. (2011). Hospitality crisis management practices: The case of Indian luxury hotels. International Journal of Hospitality Management, 30, 367-374.

Jallat, F., \& Shultz, C.J. (2010). Lebanon: From cataclysm to opportunity-Crisis management lessons for MNCs in the tourism sector of the Middle East. Journal of World Business, 46(4), 476486.

Liu, X., Chang, Z., \& Zhao, P. (2009). Is it simply a matter of managerial competence? Interpreting Chinese executives' perceptions of crisis management. Public Relations Review, 35, 232-239.

McConnell, A. (2011). Success? Failure? Something in-between? A framework for evaluating crisis management. Policy and Society, 30(2), 63-76.

Miller, S. A. (2011). April 2010 UK Airspace closure: Experience and impact on the UK's airtravelling public and implications for future travel. Journal of Air Transport Management, 17(5), 296-301.

Pearson, C.M., \& Sommer, S.A. (2011). Infusing creativity into crisis management: An essential approach today. Organizational Dynamics, 40, 27-33.

Tarraf, H. (2011). The role of corportae governance in the events leading up to the global financial crisis: Analysis of aggressive risk-taking. Global Journal Of Business Research, 5(4), 93-100.

Valackiene, A. (2010). Efficient corporate communication: Decisions in crisis management. Engineering Economics, 21(1), 99-110. 